\title{
Environmental Audit in the Sustainable Development of Green Economy
}

\author{
By Karina Nazarova ${ }^{1}$, Mariia Nezhyva ${ }^{1}$, Anatolii Kucher ${ }^{2}$, Volodumyr Hotsuliak ${ }^{1}$, \\ Tetiana Melnyk ${ }^{1}$, Olha Zaremba ${ }^{1}$
}

\begin{abstract}
The aim of the article is to present the results of a study of the main problems and prospects for sustainable development of a green economy in Ukraine, as well as, using the example of forestry, the key aspects of environmental audit in ensuring sustainable forest management are identified. The results show that environmental audit can make a positive contribution to the sustainable development of a green economy. However, in Ukraine, as in other developing countries where economic goals dominate over environmental ones, the role of environmental audit is still limited. The methodology of conducting an audit has been improved in terms of assessing the possibility of reliable economic assessment of audit subjects to further reflect its results in analytical studies. It is established that the subject of internal economic and environmental audit is a set of economic, environmental, social, informational, organizational and other subsystems in the forestry system. It is determined that to optimize the cost structure, it is advisable to control the compliance of the amounts declared in the primary accounting documents - the amounts involved in the calculation of production costs.

Keywords: green economy, sustainable development, environmental audit, Ukraine.
\end{abstract}

\section{Introduction}

In order for the global society to emerge from the socio-economic COVID crisis, as well as to reduce its high level of eco-anxiety of various etymologies, it is necessary to restore public confidence in effective management of key segments of the national economy as an imperative of national security. According to Eurobarometer surveys [5], even before the pandemic, $68 \%$ of Europeans believed that corruption was common, and 3\% of respondents directly witnessed it. In the Transparency International-19 Corruption Perceptions Index, Ukraine ranked 129th out of 180 countries (with an index of 30). In Ukraine, the vast majority of systemic problems are related to corruption. In order to overcome corruption, on November 5, 2020, the Verkhovna Rada adopted a draft law on anti-corruption strategy until 2024; 06.11.2020 The government has published the results of the state audit, according to which citizens have lost 1 trillion $\$$ in 10 years due to constant changes in the vectors of reform, corruption, etc. Society's way out of the permanent state of eco-anxiety is possible only if the public information space is filled with sound messages about overcoming corruption risks, which are aimed at effective anticorruption audit, which should be based on the results of basic research.

The key problem at the global and national levels, which manifested itself globally in 2020, is the rapid growth of the world's eco-anxiety. The COVID crisis is a manifestation of the global financial and economic, environmental, social and political crisis and is a serious challenge for the world in general and Ukraine in particular. Non-compliance with 
environmental obligations, conflicts of interest and contradictions between the provisions of different acts of equal legal force in resolving the same issue, which allows for different interpretations of norms and requirements, create a basis for abuse. This problem can be solved by implementing institutional measures of anti-corruption audit, which will help to overcome the eco-anxiety of society and effectively combat corruption and abuse.

Today, society is faced with the need for an urgent solution to global environmental problems at both global and national levels. The aggravation of the ecological situation in the world, caused by the uncontrolled anthropogenic impact of economic entities on the environment, currently threatens the very fact of healthy human existence. The most pressing environmental issues were the main topic of discussion at this year's World Economic Forum in Davos (Switzerland, 2020), which emphasized the need for sustainable development in the following areas: materials, food, transport and emissions. A survey of businessmen and politicians in preparation for the forum found that, for the first time in many years, global risks and challenges related to climate change had topped the top five, displacing economic instability and cyber threats. This indicates the growing eco-anxiety of society and the need to find ways to solve environmental problems. Ukraine's environmental safety is no exception to this situation, as it is determined by the serious consequences of the impact of negative externalities of economic entities: exceeding the permissible levels of pollution of groundwater, water bodies, air, etc. The data of the analytical report "Basic study of the state and directions of development of environmental policy of Ukraine and prospects for strengthening the participation of civil society organizations in the development and implementation of environmentally friendly policies", prepared by order of the International Renaissance Foundation (period: 2018 January 2019) environmental problems that Ukraine is currently facing. These include climate change, air pollution, water problems, soil degradation and pollution, subsoil exploitation, biodiversity conservation, waste management, land use problems (illegal amber mining) and others. To a large extent, these problems are due to numerous violations in these areas, which are permanent. Violations of state standards on product quality, emission limit values, and environmental pollution must be permanently detected and prevented by the competent authorities by ensuring effective control by both the state and non-governmental public institutions. However, due to the high level of corruption in the country, currently legally established mechanisms for environmental control in Ukraine are not really effective. This points to the importance of developing effective tools to combat corruption and environmental fraud. Anti-corruption audit plays an important role in the fight against corruption and ensuring compliance with anti-corruption programs. Anti-corruption audit is an activity of state bodies and non-state professional organizations aimed at verifying compliance with the requirements of the legislation (primarily the Law of Ukraine "On Prevention of Corruption"), as well as ethical norms. Currently, the effective implementation of anti-corruption audit in the environmental sphere requires proper development and justification of theoretical, methodological and practical principles of its implementation and implementation to ensure overcoming the eco-anxiety of the community.

The analysis of the content of literary sources showed that a number of publications are devoted to the issues of information support of economic transactions, among which the works of N. Boychenko [2], S. Gensiruk [9], G. Hulyk [11] are particularly worth 
mentioning. It is also worth noting the work of the following scientists: N. Dorosh [4], P. Ivanyuta [12], O. Koval [17], A. Lialiuk [20], V. Malikov [21], V. Mirza-Sidenko [23], Y. Petliuk [27], A. Pechenyuk [26], M. Pushkar [29], O. Sakal [32, 33], L. Saxno [31], M. Khvesik [15], I. Yarema [41], R. Roy [30] and others. B. Bui and C. Villier [3] explores accounting technologies can be used to help stimulus packages achieve the twin goals of economic stimulus and climate mitigation. K. Salhofer and P. Feichtinger [34] notes that nearly 80 percent of Common Agricultural Policy expenditures are spent on three different measures: first pillar payments, agri-environmental payments and less favoured area payments. N. Mohring, M. Bozzola, S. Hirsch and R. Finger [24] notes that the reduction of adverse health and environmental effects from pesticide use is currently a top priority on the agricultural policy agenda. R. Gallenstein, J. Flatnes, J. Dougherty, A. Sam, and K. Mishra [8] notes that index insurance increases demand for credit and high-risk highreturn investments.

Yu. Vertakova and V. Plotnikov [40] presents the results of the analysis of the economic, environmental and social development of the countries of the world in the modern period in conjunction with measures of state regulation, aimed at eliminating the negative impact of the development of the economic system on the environment and implementation sustainable development concept. They also studied the issue of green supply chain management as a tool for transforming the economy in the transition to the concept of sustainable development [39]. V. Pavlyk [25] analysis of the green investment impact on the energy efficiency gap. A. Shkuropat and V. Stepanov [35] propose to include the main indicators of "green" growth in national and regional blocks of multi-regional models. A special place is given to testing the effectiveness of "green" economy measures. C. Gribincea, and A. Gribincea [10] notes that the green economy is the future of world economy. O. Karpenko, L. Turenko and H. Karpenko [13] focus on the institutionalization of the process of greening the Ukrainian national model of the green economy. V. Potapenko, Y. Khlobystov and R. Kornatowski [28] notes that green modernization of economy through analysis of barriers and drivers based on interviewing of the companies. I. Zamula, M. Tanasiieva, V. Travin, V. Nitsenko, T. Balezentis and D. Streimikiene focus on the assessment of the profitability of environmental activities in forestry [42].

Various environmental and economic aspects of greening the agriculture as a leading sector of the economy in Ukraine are reflected in the works of the following scientists: Y. Bilan, M. Zos-Kior, V. Nitsenko, U. Sinelnikau and V. Ilin [1], Yu. Khalep and A. Moskalenko [14], O. Kotykova, M. Babych and T. Oliinyk [16], L. Kucher, S. Drokin and Y. Ulko [18], I. Makarenko, O. Kravchenko, N. Ovcharova, N. Zemliak and S. Makarenko [19], V. Stadnyk, G. Pchelianska, Yu. Holovchuk and L. Dybchuk [36], V. Zhuk, I. Zamula, D. Liudvenko and Ye. Popko [43].

At the same time, in our opinion, the problem of accounting, analysis and audit of the provision of rational forest management is insufficient, and therefore requires a more thorough assessment.

\section{Materials and Methods}


The aim of the article is to present the results of a study of the main problems and prospects for sustainable development of a green economy in Ukraine, as well as, using the example of forestry, the key aspects of environmental audit in ensuring sustainable forest management are identified.

In the course of the research, the theoretical and methodological base consisted of general scientific and special methods of cognition based on the systematic approach to the consideration of economic processes. To solve these problems, the following methods were used: analysis and synthesis methods - to study the problems and prospects of sustainable development of the green economy, as well as environmental audit of forestry enterprises; systematic analysis - to determine the methodological bases of formation of enterprise management system; comparative analysis and graphical visualization of research results. In addition, the complex of complementary methods of scientific research of economic processes and phenomena using statistical and analytical materials, as well as the results of own scientific researches were used.

\section{Results}

The concept of "green economy" has become especially important in recent years. It is widely discussed by economists and politicians in the context of sustainable development and the eradication of poverty, backwardness, and hunger. The concept of the "green economy" is based on ideas such as the welfare economy, environmental economics, anti-globalization, the theory of international relations and others related to sustainable development. In the United States, the green economy produces more than 600 billion $\$$ in products and services. USA (4.2\% of GDP), employment is estimated at 3 million people; in Japan $-3.4 \%$ of GDP and almost 1.5 million people, respectively; in the EU $-2.5 \%$ of total GDP and more than 3.4 million people. At the same time, in some EU countries the figures are generally higher: in Germany - about 4.8\% and the world leader in exports of environmentally friendly goods and services, in particular, more than $12 \%$ of world trade in climate protection equipment; in the United Kingdom, which is the world leader in the share of "green" industry in GDP $-8.8 \%$ or 240 billion $\$$, the share in exports is $5 \%$, employment $-3 \%$ [6].

In fact, the green economy is seen as a path to sustainable development that combines three components: economic, social and environmental. In Ukraine, measures were proposed aimed at greening all sectors of the economy in the public and private sectors, among which are: rational use of natural resources, diversification of energy sources and energy efficiency, creating conditions for healthy population, new environmental behavior. in matters of resource conservation, environmental protection, production of organic agricultural products, modernization of the housing and communal sector, introduction of new technologies for waste disposal and recycling. Ukraine has significant world reserves of chernozem, recreational resources, favorable climatic conditions and is one of the first places in Europe in terms of reserves of major minerals per capita. However, Ukraine is one of the energy-scarce countries, covering its needs by about $60 \%$, most of the technologies used are energy-intensive, pollute air, water and soil, products are the most energy and raw materials in the world, and resource conservation is not a priority for economic growth. The crisis in the environment, the rapid depletion of fossil fuels, 
Ukraine's dependence on imported energy requires the wider use of alternative energy sources. The main renewable energy sources are wind energy, solar energy and bioenergy. Today, the countries that occupy leading positions in the development of alternative energy sources in Europe are: Iceland $-25 \%$ of the country's energy balance is occupied by geothermal energy; Denmark - more than $20 \%$ of energy is produced by wind turbines; Portugal - about 18\% of all energy is extracted from sea waves, sunlight and wind; Spain - more than $17 \%$ of energy is produced by various solar installations [6].

Ukraine has sufficient potential to use alternative energy sources. Thus, in particular, the annual technically achievable energy potential of solar energy for Ukraine is equivalent to 5 billion $\mathrm{m}^{3}$ of natural gas, solar energy is already widely used in heating systems, to generate electricity for public and private buildings. The development of wind energy in Ukraine is promising due to the availability and renewable nature of this resource. One of the most common and available energy sources is biomass, the main component of which in Ukraine is primary waste from agriculture and landfills, the use of which, provided the introduction of modern technologies is environmentally friendly. But a deterrent to the development of bioenergy in our country are subsidies for traditional energy resources.

An important area of the green economy is the modernization of housing and communal services of Ukraine, which involves the reconstruction of residential buildings, flexible design and construction of new energy-efficient residential buildings with minimizing emissions, safe and clean shipment, removal, storage, disposal and processing of solid waste. providing clean water.

One of the promising sectors for the development of the green economy in Ukraine is agriculture, in particular - organic farming. Ukraine has all the prerequisites for this: large areas of chernozem, low use of pesticides and chemical fertilizers, a significant share of small farmers and labor availability, export potential for Western Europe. However, 90\% of domestic organic products are exported: sales on national markets have a low profitability $-70 \%$, while sales in Europe $-200 \%$. The formation of the national market of organic products is complicated by two problems - the lack of popularity of the idea of clean products and high prices for the population. Consumers of these products are mainly middle- and high-income people. According to Ukrainian experts, potential consumers of organic products in Ukraine are about $5 \%$ of the population of large cities, who are willing to pay for it $30-50 \%$ more than for conventional products. The entry of national producers into the world market of organic products is complicated by the non-compliance of Ukrainian goods with international norms and standards, the complexity of the certification process. "Greening" of agriculture involves not only the production of organic products, but also the cultivation of energy crops and their use for energy purposes, which will switch to environmentally friendly biofuels, achieve independence from traditional energy sources and reduce their supply costs [6].

An important area of green economy is rational forest use. Forest cover in Ukraine is $16 \%$ (forest cover is the ratio of the area of land covered with forest vegetation to the total area of the region). Due to natural conditions and the impact of economic activity, forests in Ukraine are unevenly distributed. They are concentrated mainly in the Western (33\%) and Northern (30.5\%) region, in the Southern region, forest cover is only - 5\% (Fig. 1) [22]. 


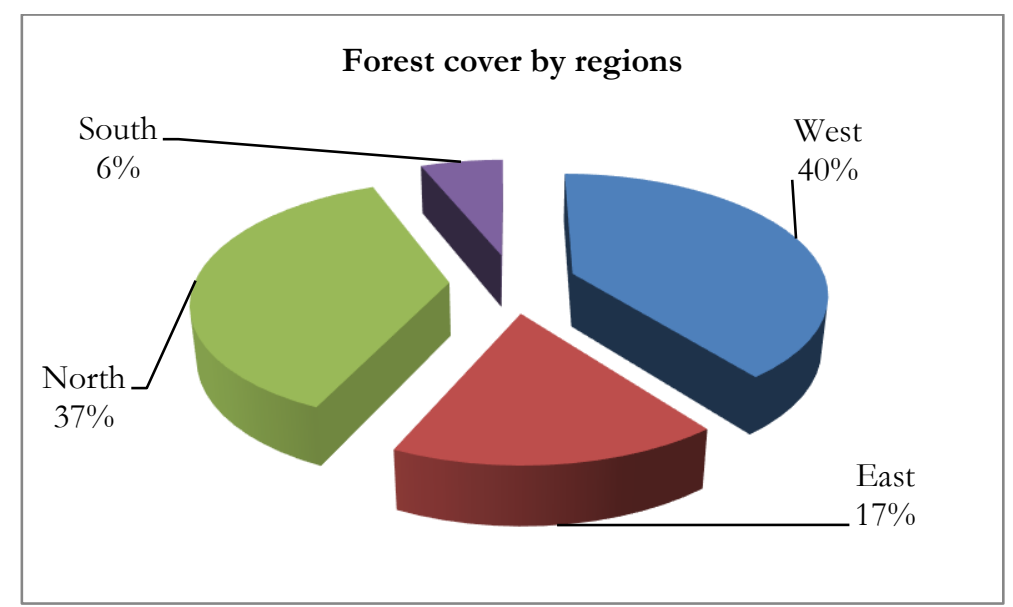

Figure 1: Forest cover by regions of Ukraine in 2019

Source: summarized by authors based on [22].

Today, forest management is mostly inefficient and leads to their degradation, rather than to responsible and rational use by all stakeholders. The Forest Stewardship Council (FSC) has created voluntary forest certification that promotes environmentally responsible, socially profitable and economically viable forest management around the world. FSC has proven to be an effective tool that invites people to influence the environment through their consumer decisions. FSC certification works along the entire chain from the forest to the consumer and contributes to improvements in the economic sphere, expands the rights and opportunities of society, improves the quality of the environment. According to the position of FSC Ukraine, responsible forest management can ensure that the harvesting of timber and non-timber forest products will not threaten biodiversity, will not reduce the productivity and environmental functions of forests.

In Ukraine, certification has been valid for 15 years. As of 2020, more than $60 \%$ of forestries in the Western and Northern regions have passed it. According to the official website of FSC Ukraine [33], as of 2020, the largest share of FSC-certified forest areas falls on the Volyn region. Instead, there is no certified forestry in the Southern region (Fig. 2). 


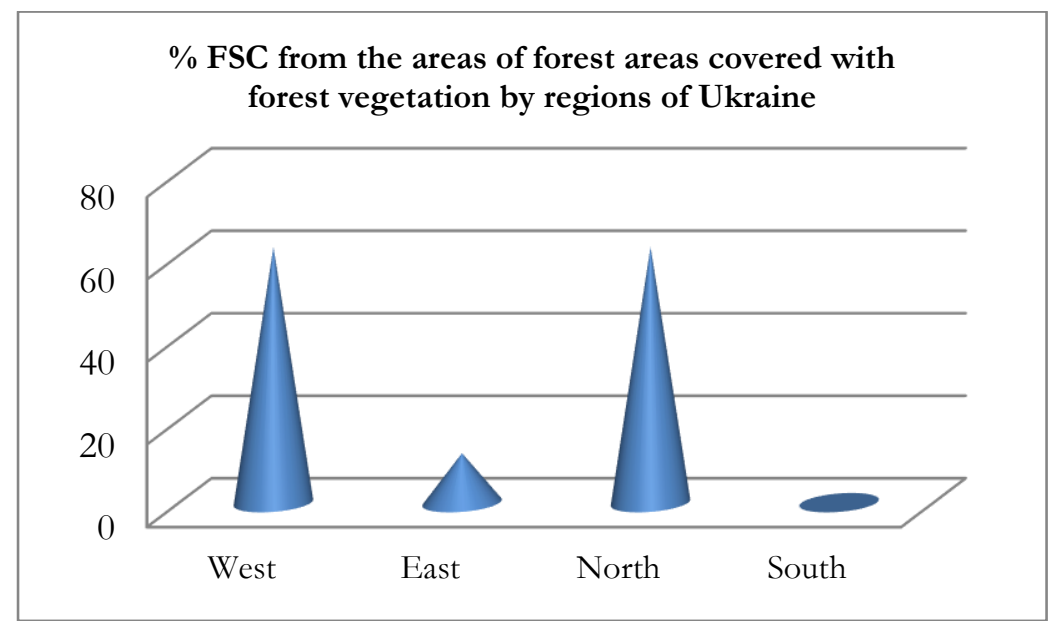

Figure 2: \% FSC from the areas of forest areas covered with forest vegetation by regions of Ukraine in 2020. Source: summarized by authors based on [7].

One of the problems of the forest industry is illegal logging. Illegal logging is the harvesting of timber without a special permit for the use of forest resources (logging ticket). According to the State Agency of Forest Resources [34], the cyclical nature of cases of illegal logging is inextricably linked with the rise or fall of levels of economic activity in Ukraine (Fig. 3). The number of officially recorded violations is: the largest in the Northern (3484 units) and Western (2706 units) regions; the smallest - in the Southern region (Fig. 4).

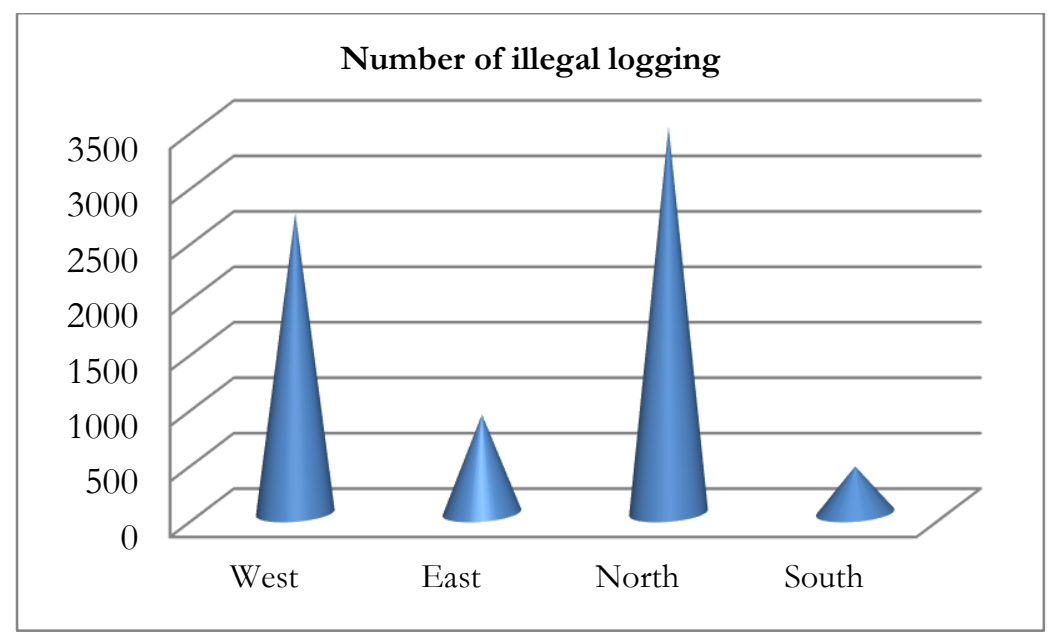

Figure 3: Number of illegal logging in Ukraine in 2020.

Source: summarized by authors based on [37]. 


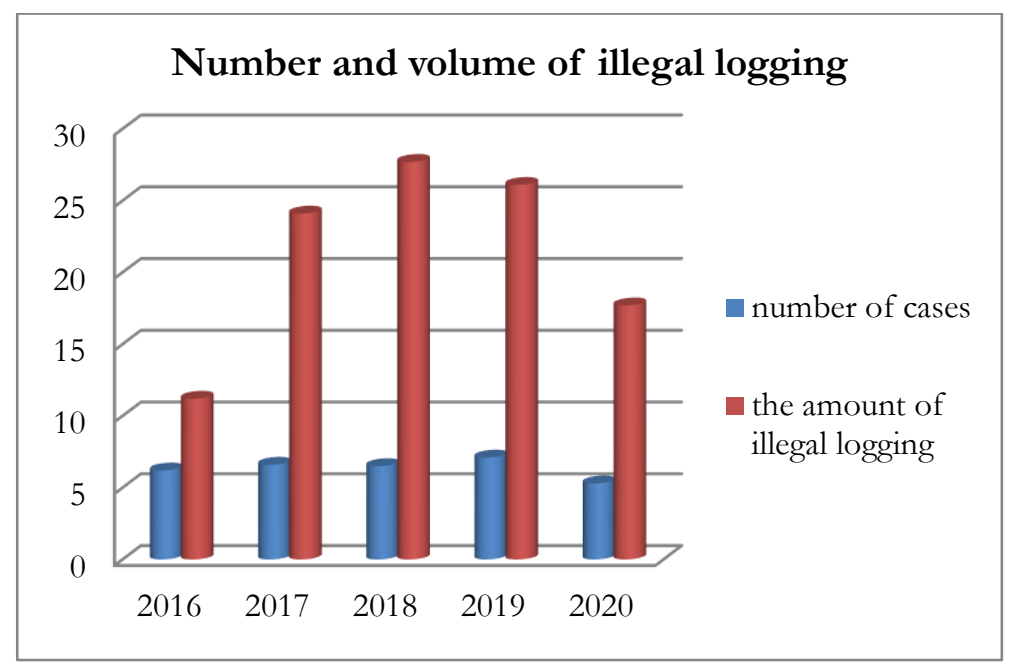

Figure 4: Number and volume of illegal logging in Ukraine in 2016-2020.

Source: summarized by authors based on [37].

Ukraine is one of the European leaders in amber reserves. Ukrainian companies that have state licenses for amber mining extract about 4 tons of this mineral annually. However, in reality, this is only a small percentage of actual amber mining in Ukraine. It is much more dug by miners in illegal trades that are not controlled by the state. Activity on illegal amber mining is observed mainly in the Northern region within the Zhytomyr region (Olevsk, Ovruch and Korosten districts), Rivne region (Rokytne, Dubrovytsia, Volodymyrets, Zarichne and Sarny districts) and Volyn and Lyubiv (Ratni). Among the main negative consequences of illegal amber mining are the following: violation of the integrity of geological rocks; violation of hydrogeological conditions in the adjacent territories; destruction of grass cover and fertile soil layer; felling of trees and violation of their root system; change of wetland biocenoses; provoking the intensification of water and wind erosion.

The main priorities of Ukraine's environmental policy, including as areas of environmental policy that are promising for the activity of the public, business, government are: climate change; ensuring ecologically balanced nature management; protection of natural resources and natural complexes and systems: atmospheric air, waters, lands and soils, forests, subsoil, biological and landscape diversity, NPF / ecological network; emergencies of natural and man-made nature; waste and hazardous chemicals; biological security; integration of environmental policy and improvement of the system of integrated environmental management; environmental education and training, access to environmental information and decision-making; regional environmental policy; environmental fees. The main ecological problems of biodiversity of Ukraine (by regions) are given in Table 1 [22].

The priority task has set before forestry enterprises is reforestation. There are natural (seed and vegetative), artificial (sowing and / or planting of seedlings and saplings) and combined (combination of natural and artificial in the same area) reproduction of the forest. To maintain and increase the forest resource potential, it is important to carry out 
forest protection works - on time and in full. One of the main tasks facing forest users is to comply with sanitary rules in forestry and forest management in terms of sanitary and health measures, organization and conduct of forest pathological supervision and inspections, control of forest pests and diseases, elimination of fires and localization of fires. Objective reasons that directly affect the reduction of the effectiveness of protective work are: reduction of forestry funding, misuse of budget funds, lack of an extensive network of forest roads, rising cost of spare parts, fuel and lubricants and other materials, etc.

Table 1: Main ecological problems of biodiversity of Ukraine

\begin{tabular}{|l|c|c|c|c|}
\hline \multicolumn{1}{|c|}{ Indicator } & West & East & North & South \\
\hline $\begin{array}{l}\text { The share of NPF in the } \\
\text { total area of the region }\end{array}$ & $\begin{array}{c}\text { the problem is } \\
\text { relevant }\end{array}$ & $\begin{array}{c}\text { the problem } \\
\text { is acute }\end{array}$ & $\begin{array}{c}\text { the problem } \\
\text { is relevant }\end{array}$ & $\begin{array}{c}\text { the problem } \\
\text { is acute }\end{array}$ \\
\hline $\begin{array}{l}\text { Real forest cover VS optimal } \\
\text { forest cover }\end{array}$ & $\begin{array}{c}\text { the problem is } \\
\text { acute }\end{array}$ & $\begin{array}{c}\text { the problem } \\
\text { is acute }\end{array}$ & $\begin{array}{c}\text { the problem } \\
\text { is acute }\end{array}$ & $\begin{array}{c}\text { the problem } \\
\text { is acute }\end{array}$ \\
\hline \% FSC certified forests & $\begin{array}{c}\text { the problem is } \\
\text { relevant }\end{array}$ & $\begin{array}{c}\text { the problem } \\
\text { is acute }\end{array}$ & $\begin{array}{c}\text { the problem } \\
\text { is relevant }\end{array}$ & $\begin{array}{c}\text { the problem } \\
\text { is acute }\end{array}$ \\
\hline Illegal logging was recorded & $\begin{array}{c}\text { the problem is } \\
\text { acute }\end{array}$ & $\begin{array}{c}\text { the problem } \\
\text { is relevant }\end{array}$ & $\begin{array}{c}\text { the problem } \\
\text { is acute }\end{array}$ & $\begin{array}{c}\text { the problem } \\
\text { is relevant }\end{array}$ \\
\hline
\end{tabular}

Source: summarized by authors based on [22].

In the structure of dead forest plantations, a significant share is occupied by forest losses due to fires (Fig. 5). Forest fires are spontaneous, uncontrolled spread of fire in a forest area. Occurs in the presence of combustible materials and sources of fire, meteorological conditions favorable for forest fires. The main cause of forest fires is anthropogenic factors.

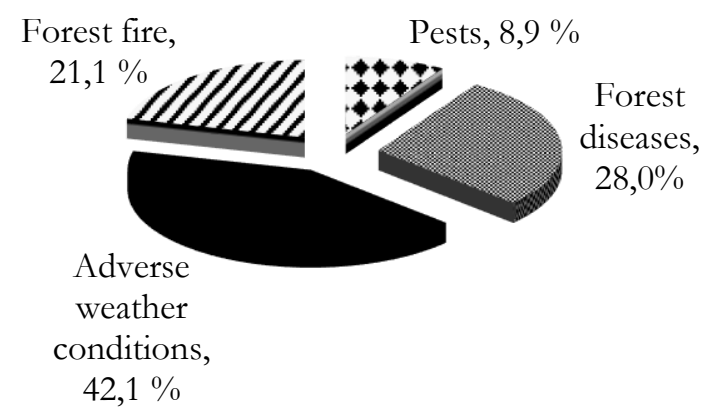

Fig. 5. The structure of dead forest stands

Source: summarized by authors based on [38]. 
Today, the issue of preventive measures to prevent fires remains relevant. Reliable means of increasing the fire resistance of plantations are: growing mixed in composition and complex in structure stands; creation of protective meadows from deciduous breeds inside arrays of coniferous young growth. The effectiveness of forest fire fighting also depends on compliance with logging rules, clearing of felling sites, creation of firebreaks, ruptures and mineralized strips, arrangement of fire reservoirs, fire propaganda, staffing of ground forest protection and its modern means of surveillance, etc.

However, despite the fact that Ukraine is one of the forest-deficient states, imperfect legislation on criminal and administrative liability for illegal logging (until April 2019), a large area of forests per 1 full-time forest worker and lack of funding from the state budget for protection and preservation of forests did not reduce the incidence of illegal (unauthorized) felling and poaching and led to damage in the amount of 1 billion UAH, of which 0.8 billion UAH by unidentified persons [38].

A comparative analysis of the material damage established and compensated by the perpetrators, caused as a result of violations of legislation in the field of forestry and hunting and hunting for 2017-2019, indicates that even half of the damage is not reimbursed (Table 2).

Table 2: Comparative analysis of the material damage established and compensated by the guilty persons caused as a result of violation of the legislation in the field of forestry and hunting and hunting for 2017-2019

\begin{tabular}{|l|c|c|c|c|}
\hline \multicolumn{1}{|c|}{ Violation of the law } & 2017 & 2018 & 2019 & $2017-2019$ \\
\hline Detected, thousand UAH & 16309,4 & 26692,6 & 17760 & 60762 \\
\hline Reimbursed, thousand UAH & 6242,3 & 8144,7 & 6613,9 & 21000,9 \\
\hline Reimbursed, \% & 38,3 & 30,5 & 37,3 & 34,6 \\
\hline Absolute deviation, thousand UAH & 10067,1 & 18547,9 & 11146,1 & 39761,1 \\
\hline
\end{tabular}

Source: summarized by authors based on [38].

For 2017-2019, for 9 months of 2020, illegal logging amounts to 162,314 cubic meters with a total cost of forest damage of 1 billion UAH, of which unidentified persons 138,010 cubic meters with a total cost of forest damage of 0.8 billion UAH [38].

Also, forest accounting aims to provide:

- timely, high-quality and reliable reflection of the movement of forest products;

- control over the work of materially responsible persons;

- obtaining data on forest product residues;

- control over storage and use of forest products;

- accounting and control over the payment of shipped timber products;

- taking measures to prevent shortages, thefts and illegal consumption of forest products;

- carrying out planned and sudden inventories of forest products at storage sites to verify the actual availability with accounting data.

To date, the Government of Ukraine has introduced a pilot project for a logging register and an online map of logging "Forest in a smartphone". Every citizen can go from the computer or phone to the website LK.UKRFOREST.COM and read the list of logging tickets for logging or check the legality of logging on the map. The organization of electronic timber accounting from the removal of loggers to the acceptance of finished products will allow in real time to obtain information about the timber market in the 
country. Accounting for timber at the branches is an important element of the organization of domestic sales of wood and the neutralization of its shadow market. Introduction of the newest technologies of electronic accounting and marking of wood will allow to increase efficiency of accounting of forest products, to strengthen responsibility of each forester, to release foresters from routine paper work, to accelerate information exchange from foremen's site to forestry, to control further movement of wood from felling to concrete consumer. It will also help speed up accounting, timber accounting and the issuance of supporting documents.

As for the audit of forest assets, it should be conducted in order to independently assess the legality, feasibility, economic and environmental efficiency of operations related to afforestation and logging.

The main procedures that require a mandatory economic and environmental audit include:

- calculation of the size, distribution and allocation of costs for the establishment and cultivation of forest nurseries, plantations and different age groups of plantations - are subject to verification for objectivity and reliability;

- allotment of plots for various types of felling related to the main use, forestry, other felling and elimination of clutter - require verification of the legality, environmentally and economically justified size of forestry work;

- substantiation of the size, distribution and allocation of reforestation costs (for areas covered by continuous and selective felling, afforestation of waste, eroded lands and other lands unsuitable for agriculture) - are subject to verification of expediency and reliability;

- determination of the size, distribution and allocation of costs for the control of forest pests and diseases - require verification of economic feasibility, and standards for the use of pesticides and agrochemicals - for environmental feasibility;

- calculation of the value, distribution and allocation of costs for forest protection from fires subject to verification for reliability and environmental efficiency;

- harvesting of resin, wood sap and other secondary forest materials - need to be checked for environmental feasibility.

Important to cover the audit also operations on timber extraction, its valuation, initial recognition, posting, sale, etc.

Given the specifics of forestry activities, the first step is to plan an internal audit, when it is important to develop a main strategy and specific approaches to the nature, period and timing of the audit. In addition, it is necessary to assess the possibility of a reliable economic evaluation of the audited entities to further reflect its results in analytical studies. Priorities for the solution remain the issues of economic assessment of environmental consequences from unauthorized removal of wood, damage to forest plantations by pests, diseases, forest fires (unauthorized and / or intentional), etc. Additional tasks at this stage are:

- development of a plan and program of audit work;

- selection and determination of the general condition of the audited entity;

- substantiation of the directions of use of audit results;

- development of a system of synthetic and analytical indicators that characterize the audited entity. With regard to the organization of internal audit, at this stage it is advisable to appoint auditors (because the complexity of the audit requires the involvement of specialists in various specialties foresters, economists, accountants) and prepare information and logistics of audit procedures. The main sources of information used for internal economic and environmental audit include: 
- planned - all types of plans developed at the enterprise, as well as regulatory materials, estimates, project tasks;

- accounting - all data contained in the documents of accounting, statistical and operational accounting (together with forestry and tax information), as well as all types of reporting, primary accounting information;

- off-account - documents governing the economic activity of the enterprise.

The next step is the direct processing of the prepared information and the implementation of a set of additional audit procedures that increase the reliability of the results of internal audit. The main measures at this stage we consider appropriate to highlight:

- checking the completeness and reliability of reporting data, conducting arithmetic, logical and balance sheet indicators;

- determination of general deviations of the value of performance indicators from the basic values;

- assessment of interacting factors and calculation of their impact on the change in the value of indicators;

- identification of unnecessary costs and unused opportunities (prospective reserves) to increase the efficiency of forest use.

In the action system to ensure compliance with accounting and control functions of management occupies an important place control over auditing and evaluation results. The conclusions of the internal environmental audit are the basis for making management decisions that increase the efficiency of sustainable forest management. In addition, high-quality internal economic regulation of the processes of formation, use and reproduction of forest assets ensures the implementation of a policy of inexhaustible and environmentally-oriented forestry. Therefore, at this stage it is necessary:

- conduct a final evaluation of the activities and summarize the results of the audit;

- formulate specific recommendations for making appropriate management decisions based on the audit findings, in accordance with its goals and objectives;

- develop organizational and technical measures to eliminate the identified shortcomings and increase the efficiency of the identified reserves (through, for example, deepening the rational development of wood, optimizing the processes of allotment of plots for timber extraction, etc.);

- prepare administrative acts, orders, appointments of persons responsible for the implementation of decisions;

- control the implementation in production of proposals that have been put forward as a result of the audit.

The internal audit system distinguishes general elements that generally characterize certain aspects of its implementation, such as the subject, functions, audit methods, etc. and individual, which are specific to specific forestry sectors (eg, objects and audit techniques for industrial forestry will differ from similar ones for social forest use and in forestry).

The subject of internal economic and environmental audit is a set of economic, environmental, social, informational, organizational and other subsystems in the system of forestry.

The main functions of internal audit are: prevention (reduction) of environmental threats in the conduct of operations related to the use of forest resources; assessment of the state of accounting and internal control, their permanent monitoring and development of recommendations for optimization of these systems; research of accounting and operational information for its reliability and objectivity, including verification of tools used to obtain information, summarize it and compile reports, as well as detailed 
processing of individual reporting items; checking the level of compliance with the requirements of laws and other regulations governing the economic and environmental activities of forestry enterprises, as well as the provisions of accounting policies, internal instructions, decisions and guidelines of the management staff; assessment of the effectiveness of the implementation of the mechanism of internal control of enterprises in general and control procedures in their structural units in particular; checking the availability, condition and conditions of preservation of material resources of state forestries; analysis and evaluation of software used by enterprises to increase the reliability of accounting data; special official investigations of individual cases related to the formation, use and / or reproduction of forest assets, on behalf of the head; drawing up and providing conclusions and reports after the completion of the work performed; search for opportunities and development of proposals to address the identified shortcomings and recommendations for improving the efficiency of forest management.

Regarding the method of internal audit, it should be noted that this is a set of research techniques that determine the approach to the objects being studied. General methods of audit are: analysis and synthesis, analogy and modeling, abstraction and concretization, systems analysis, functional-cost analysis, etc. Such research methods as cluster, factor analysis (to narrow the range of indicators important for evaluation), methods of questionnaires, interviews, expert assessments and others allow to specify and deepen the internal economic and environmental audit of forest enterprises.

The main objects of internal economic and environmental audit are, respectively, forests, wood products.

To ensure a comprehensive economic and environmental audit of forestry operations, it is necessary to check:

- legality and validity of determining the scope of work on reforestation and afforestation, protection of forests from fires, protection from pests and diseases, other forestry measures, as well as the procedure and methods of their implementation;

- the reliability of the allocation of costs of cash and material resources in terms of the above operations;

- compliance of the volumes of used material resources (especially ecologically dangerous pesticides) with ecologically safe norms (according to the instructions of instructions for use of drugs);

- legality of allotment of plots for sanitary felling (continuous and selective), care felling (lighting, cleaning, thinning, passage), reforestation, reconstructive felling, etc. and volumes of liquid wood and secondary forest materials removed as a result (stump, bast, bark), woody greens);

- the reliability of the allocation of costs for felling of intermediate use;

- complete afforestation on lands intended for creation of forests (not covered with forest vegetation, first of all low-productive and unsuitable for use in agriculture (ravines, gullies, sands, etc.), on agricultural lands allocated for creation of field protective forest strips and other protective plantings);

- completeness of reforestation works on forest areas covered with forest vegetation (fellings, fires, etc.);

- legality of repayment of expenses aimed at increasing productivity, improving the quality of stateowned forests, their reproduction and protection at the expense of the state budget;

- reliability of forest management materials, which provide qualitative and quantitative characteristics of each forest area and a comprehensive assessment of forest management. 
The principle of reliability and completeness of the information used for the audit requires a detailed study:

- acts of inspection of places of timber, other forest products and use of useful properties of forests;

- acts of technical acceptance of forest crops;

- acts of transfer of lands not covered with forest vegetation into lands covered with forest vegetation;

- acts of inspection in case of change of categories of lands as a result of economic activity, natural phenomena and other factors;

- acts of inspection of land forest plots when changing their purpose (use for purposes not related to forestry);

- acts of inspection of forest areas affected by pests and diseases;

- acts of inspection of forest areas damaged by forest fires;

- acts and conclusions of the commissions on allocation of sites (selection of trees marked for removal from forest stands) for sanitary and care felling.

Additional sources of information are forest management materials, primary accounting documentation, financial and statistical reporting.

The system of accounting and auditing management of rational forest management will not be complete without internal accounting and control over logging processes and the sale of forest products, as these components ensure the economic efficiency of forestry enterprises. The financial resources obtained as a result of management contribute to the self-sufficiency and self-financing of the industry, they allow to fully restore forest plantations, enrich biological diversity, increase the ecological potential of the forest biogeocenosis. Therefore, it is important to objectively assess the production and financial operations in forestry, which is achieved through their reliable accounting and internal economic and environmental audit.

The system of economic relations can include not only conditioned wood, but also waste, which often surpasses liquid wood in its individual quality characteristics. Thus, branches and twigs of spruce, pine and aspen contain more than the trunk of lignin - by $18.3 \%$, pentosans - by $4.5 \%$, ash - by $45.4 \%$. In the conditions of sparsely forested and forestdeficient Ukraine, the resources of this potential raw material are quite significant, and their use in economic circulation has both ecological and social significance [31]. For example, lignin-containing waste is used in the reclamation of non-agricultural land, by diluting and germinating plant seeds in them, which over time leads to the formation of a new layer of soil. Wood ash can be used as fertilizer, in composting plant residues, for the preparation of nutrient solutions in pre-sowing seed preparation and the like. Under these conditions, one of the main tasks of the internal economic and environmental audit of the logging process is to assess the feasibility of writing off raw materials in waste, economic efficiency of their full use and environmental feasibility of disposal.

Accounting and auditing support of rational forest use also includes regulation of harvesting of secondary forest materials - stumps, bast, bark, wood greens, etc. On the basis of logging tickets, which are the main primary documents, according to which the accounting of allowed for the release of wood is important to accurately assess the yield of resources of small wood (shrubs, firewood) and waste crown.

Unfortunately, the current realities of management in the forest sector of the economy indicate the absence in the system of evaluation indicators of such efficiency criteria as the 
level of development of resources of secondary forest use, hunting fauna, recreational functions of the forest and so on. Indicators that characterize the completeness of the use of secondary forest assets are not reflected in the accounting (logging tickets indicate only the volume of commercial timber, firewood and bushes, while not taking into account logging waste that can bring economic and environmental impact from operation). In terms of major forest-forming species, the yield of liquid raw materials (under the conditions of development of crown resources) increases by an average of $8-12 \%$. Much of the waste from woodworking industries can be involved in the system of economic relations and, consequently, in production processes, which is of great environmental and economic importance. The existing technology of logging works provides operations of felling of trees and their skidding in a semi-loaded position. This causes contamination of the crown, destruction of its upper part and damage to fine wood. When the forest is removed by whips, the crown usually remains in the forest. Part of it is destroyed, and part accumulates at cargo points. That is why the waste suitable for the production of technological chips is only $4 \%$ of the volume of the trunk of the tree [38].

The results of the economic and environmental audit of forestry help to objectively assess the state of internal control over the processes of sale of forest products to prevent illegal actions and violations in the accounting system of wood products. Therefore, the next step in conducting an internal economic and environmental audit is the study of operations to reflect the movement of forest products in the account and the development of practical recommendations for optimizing decision-making on the management of economic activity in the enterprise.

To ensure internal control over the export of raw materials, it is necessary to conduct periodic checks of compliance of the data specified in the primary documents with the actual balances of forest products in warehouses by quantitative and qualitative parameters. The main audit procedures that allow to optimize control are: reconciliation of accounting data with accounting data of materially responsible persons in the places of storage of forest products (to deepen the completeness of the reflection of finished products in the account), control measurements of wood in warehouses and loggers, inspection of areas completely exported timber, secondary timber, waste.

Particular attention is paid by the internal economic and environmental audit to the assessment of the actual yield of harvested and exported timber in accordance with the volumes specified in the logging tickets, as they are the basis for calculating the poppy fee - the main and only type of wood stump fee in forestry. In cases of non-compliance of the volumes of harvested wood with those specified in the logging tickets, it is possible to talk about the fact of violation of forest legislation. Reconciliation must be carried out with the data specified in the consignment notes and directly at the place of harvesting (for example, the number of stumps in the felling).

The direct correlation between costs and the amount of work performed is objective, it should only be noted that the rate of excess costs for all types of work does not correspond to the rate of overfulfillment of these works. Under these conditions, to increase the effectiveness of management decisions on the preparation and provision of financial plans in the enterprise, it is important to assess the main factors that determine the growth of actual indicators for their objectivity and optimal balancing in the "cost-production" system. To optimize the cost structure, it is advisable to control the compliance of the 
amounts declared in the primary accounting documents - the amounts that participate in the calculation of the cost of production.

\section{Conclusions.}

The article presents the results of a study of the main problems and prospects for sustainable development of a green economy in Ukraine, as well as, using the example of forestry, the key aspects of environmental audit in ensuring sustainable forest management are identified. The green economy needs management approaches to continuous optimization based on effective and reliable data provided by the auditor. Today, there is only one world-famous tool that provides independent analysis and recommendations for various process optimizations - audit. The results show that environmental audit can make a positive contribution to the sustainable development of a green economy. However, in Ukraine, as in other developing countries where economic goals dominate over environmental ones, the role of environmental audit is still limited.

The priority tasks facing forestry enterprises have been formulated. Introduction of the newest technologies of electronic accounting and marking of wood will allow to increase efficiency of accounting of forest products, to strengthen responsibility of each forester, to release foresters from routine paper work, to accelerate information exchange from foremen's site to forestry, to control further movement of wood from felling to concrete consumer. The methodology of conducting an audit has been improved in terms of assessing the possibility of reliable economic assessment of audit subjects to further reflect its results in analytical studies. It is established that the subject of internal economic and environmental audit is a set of economic, environmental, social, informational, organizational and other subsystems in the forestry system. It is determined that to optimize the cost structure, it is advisable to control the compliance of the amounts declared in the primary accounting documents - the amounts involved in the calculation of production costs.

Prospects for further research are the development of measures for the development of green economies that will contribute to the long-term development of countries around the world.

\section{References}

1. Bilan, Y., Zos-Kior, M., Nitsenko, V., Sinelnikau, U. and Ilin, V. (2017). Social component in sustainable management of land resources. Journal of Security and Sustainability, 7(2): 107-120. https://doi.org/10.9770/jssi.2017.7.2(9).

2. Bojchenko, N. V., Kovalevska, N. S. and Naumova, T. A. (2017). Environmental audit: essence and necessity. Ekonomichna strategiya i perspekty 'vy rozvy thu sfery torgivli ta poslug, 1: 28-36.

3. Bui, B. and Villiers, C. (2021). Recovery from Covid-19 towards a low-carbon economy: a role for accounting technologies in designing, implementing and assessing stimulus packages. American Journal of Agricultural Economics, https://doi.org/10.1111/acfi.12746.

4. Dorosh, N. I. and Malinovska, D. (2016), The financial environmental audit: the nature and methods. Agrosvit, 22: 8-13.

5. Eurobarometer (2020). Available at: https://www.europarl.europa.eu/at-your-service/en/beheard/eurobarometer.

6. Environmental audit committee (2019). Six report of session, 12. 
7. FSC Ukraine (2020). Available at: https://ua.fsc.org/ua-ua/pro-nas/global strategy.

8. Gallenstein, R., Flatnes, J., Dougherty, J., Sam, A. and Mishra, K. (2021). The impact of index-insured loans on credit market participation and risk-taking. Agricultural Economics, 52: 141-156. https://doi.org/10.1111/agec.12611.

9. Gensiruk, S. A. (2002). Forests of Ukraine. Ukrainian National Forestry University, 496 p.

10. Gribincea, C. and Gribincea, A. (2019), "Green economy" - the future of world economy. Rynkova Ekonomika Suchasna Teoriia i Praktyka Upravlinnia, 3: 42-52.

11. Hulyk, G. S. (2012). Synergetic approach in the application of economic and legal instruments towards forming a sustainable forest management system. Naukoryj visnyk. NLTU Ukrayiny, 22: 331-335.

12. Ivanyuta, P. V. (2011). Environmental audit in the public governance system ecological security of Ukraine. Investyciyi: praktyka ta dosvid, 5: 86-90.

13. Karpenko, O., Turenko, L. and Karpenko, H. (2018). Modern tools for the ensuring the eco development of the national model of the "green" economy. Ekonomichni Innovatsii, 4: 78-90.

14. Khalep, Yu. and Moskalenko, A. (2020). Ecological and economic aspects of the efficiency of Polissia organic plant models. Agricultural and Resource Economics, 6(4): 5-19. https://doi.org/10.51599/are.2020.06.04.01.

15. Khvesyk, M. A., and Sakal, O. V. (2019). Financial and economic management tools for sustainable forest management. Ekonomika. Upravlinnya. Innovaciyi. Seriya: Ekonomichni nauky, 2(25). Available at: http://nbuv.gov.ua/UJRN/eui 2019 211.

16. Kotykova, O., Babych, M. and Oliinyk, T. (2020). Measures to reduce food loss and waste in Ukraine. Agricultural and Resource Economics, 6(4): 144-167. https://doi.org/10.51599/are.2020.06.04.08.

17. Koval, O. O. (2014). Ecological audit as instrument of estimation and control after the state of natural environment of enterprise. Nauka i tehnika povitryanyh zbrojnyh syl Ukrayiny, 4: 118-120.

18. Kucher, L., Drokin, S. and Ulko, Y. (2020). Ecological-economic efficiency of irrigation projects in the context of climate change. Agricultural and Resource Economics, 6(2): 57-77. https://doi.org/10.51599/are.2020.06.02.04.

19. Makarenko, I., Kravchenko, O., Ovcharova, N., Zemliak, N. and Makarenko, S. (2020). Standardization of companies' sustainability reporting audit. Agricultural and Resource Economics, 6(2): 78-90. https://doi.org/10.51599/are.2020.06.02.05.

20. Lialiuk, A. V. (2018). Features of Legal Regulation of Forest Use in Ukraine. Zhurnal skbidnoievropeiskoho prava, 51: 232-238.

21. Malikov, V. V. (2015). Environmental Audit: an Analysis of the Research Problematics. Biznes Inform, 5: $161-164$.

22. Matus, S. A., Levina, G. M., Karpyuk, T. S. and Denishchik, O. Yu. (2019). Basic study of the state and directions of development of environmental policy of Ukraine and prospects for strengthening the participation of civil society organizations in the development and implementation of environmentally friendly policies. Available at: https://www.irf.ua/wpcontent/uploads/2019/12/baseline-research report publishing-dec-2019.pdf

23. Mirza-Sidenko, V. M. and Maslova, N. M. (2018). Geographic analysis of the device of forest and use of forest in the territory of the Kirovograd region. Naukovyi visnyk Khersonskobo derzhavnoho universytetu. Seriia: Heobraficbni nauky, 9: 140-146.

24. Mohring, N., Bozzola, M., Hirsch, S. and Finger, R. (2020). Are pesticides risk decreasing? The relevance of pesticide indicator choice in empirical analysis. Agricultural Economics, 51(3): 429-444. https://doi.org/10.1111/agec.12563.

25. Pavlyk, V. (2020). Assessment of green investment impact on the energy efficiency gap of the national economy. Financial markets, institutions and risks, 4(1): 117-123. http://doi.org/10.21272/fmir.4(1).117-123.2020.

26. Pechenyuk, A. P. (2017). Ecological audit of rural green tourism facilities. Innovacijna ekonomika, 1-2: 8487.

27. Petlyuk, Yu. (2017). Legal liability for violation of legislation on environmental audit. Publichne pravo, 4: $186-191$.

28. Potapenko, V., Khlobystov, Y. and Kornatowski, R. (2017). Green modernization of Ukraine's economy: analysis of barriers and drivers based on interviewing of the companies. Environmental economics, 2: $50-56$.

29. Pushkar, M. S. and Shchyrba, M. T. (2010). Theory and practice of accounting policy formation, Ternopil, Kart- 
blansh, $260 \mathrm{p}$.

30. Roy, R. (2002). An overwiev of an Environmental audit. CF Bulletin, 8: 28-36.

31. Sahno, L. A. and Trachova, D. M. (2012). Ecological audit in the system of ecocontroling. Oblik i finansy,1: 97-100.

32. Sakal, O. V. (2019). Substantive characteristics of public-private forms of sustainable spatial development use of forest. Environmental Economics and Sustainable Development, 5, 84-90. https://doi.org/10.37100/2616-7689/2019/5(24)/13.

33. Sakal, O. V. (2018). Estimation of basic characteristics of the rental instrument for regulation use of forests. Environmental Economics and Sustainable Development, 3-4: 101-106. https://doi.org/10.37100/2616-7689/2018/3-4(22-23)/14.

34. Salhofer, K. and Feichtinger, P. (2020). Regional differences in the capitalisation of first and second pillar payments of the CAP into land rental prices. European Review of Agricultural Economics, 48(1): 8-41. https://doi.org/10.1093/erae/jbaa028.

35. Shkuropat, A. and Stepanov, V. (2019). Methodological approaches for inclusion of factors of a "green economy" into medium term forecasting models for regional development. Ekonomichni Innovatsii, 4: 199-210.

36. Stadnyk, V., Pchelianska, G., Holovchuk, Yu. and Dybchuk, L. (2020). The concept of marketing of balanced development and features of its implementation in the food market. Agricultural and Resource Economics, 6(3): 80-95. https://doi.org/10.51599/are.2020.06.03.05.

37. State Agency of Forest Resources of Ukraine (2020). Available at: http://dklg.kmu.gov.ua/forest/control/uk/index.

38. State Statistics Service of Ukraine (2020). Available at: http://www.ukrstat.gov.ua.

39. Vertakova, Yu., Kazantseva, A. and Plotnikov, V. (2020). Green supply chain management as a tool for transforming the economy in the transition to the sustainable development concept. Agricultural and Resource Economics, 6(2): 37-56. https://doi.org/10.51599/are.2020.06.02.03.

40. Vertakova, Yu. and Plotnikov, V. (2017). Problems of sustainable development worldwide and public policies for green economy. Economic annals-XXI, 166: 4-11. https://doi.org/10.21003/ea.V166-01.

41. Yarema, I. I. (2016). Theoretical and methodological approaches to ecological planning in the context of sustainable forest management. Sotsialno-ekonomichni problemy suchasnoho periodu Ukrainy, 6: 8-12.

42. Zamula, I., Tanasiieva, M., Travin, V., Nitsenko, V., Balezentis, T. and Streimikiene, D. (2020). Assessment of the profitability of environmental activities in forestry. Sustainability, 12(7): 2998. https://doi.org/10.3390/su12072998.

43. Zhuk, V., Zamula, I., Liudvenko, D. and Popko, Ye. (2020). Development of non-financial reporting of agricultural enterprises of Ukraine. Agricultural and Resource Economics, 6(4): 76-89. https://doi.org/10.51599/are.2020.06.04.05. 